\title{
Thauera mechernichensis sp. nov., an aerobic denitrifier from a leachate treatment plant
}

\author{
Edzard Scholten, ${ }^{1}$ Thomas Lukow, ${ }^{1}+$ Georg Auling, ${ }^{1}$ \\ Reiner M. Kroppenstedt, ${ }^{2}$ Fred A. Rainey ${ }^{3}$ and Hans Diekmann'
}

Author for correspondence: Hans Diekmann. Tel: +49511 7624359. Fax: +49511 7625287 e-mail: diekmann@mbox.ifmb.uni-hannover.de

\author{
1 Institut für Mikrobiologie, \\ Universität Hannover, \\ Hannover, Germany \\ 2 DSMZ - Deutsche \\ Sammlung von \\ Mikroorganismen und \\ Zellkulturen $\mathrm{GmbH}$, \\ Braunschweig, Germany \\ 3 Department of Biological \\ Sciences, Louisiana State \\ University, Baton Rouge, \\ LA 70803, USA
}

\begin{abstract}
A heterotrophic bacterial strain TL1' capable of aerobic denitrification was previously enriched in continuous culture from a landfill leachate treatment plant and isolated as a pure culture. The taxonomic position of this isolate within the $\beta$-subclass of the Proteobacteria was determined by 165 rDNA sequence analysis and by conventional taxonomy including substrate spectrum, quinone type (ubiquinone Q-8) and cellular fatty acid composition. Detection of the specific polyamine 2-hydroxyputrescine supports the membership of strain TL1 ${ }^{\top}$ in the $\beta$-subclass of the Proteobacteria. The results of 165 rDNA sequencing showed that the strain clustered with, but was separate from, Thauera aromatica and Thauera selenatis. DNA-DNA hybridization experiments indicated that the new isolate represents a new species of the genus, for which the name Thauera mechernichensis is proposed; the type strain is DSM 12266'.
\end{abstract}

Keywords: Thauera mechernichensis sp. nov., aerobic denitrification

\section{INTRODUCTION}

Although heterotrophic nitrification has been known for decades (Verstraete, 1975) and aerobic denitrification has been repeatedly reported (Carter et al., 1995a), it was ultimately the work of Robertson \& Kuenen (1984) on Thiosphaera pantotropha GB17 (now Paracoccus denitrificans DSM 2944; renamed as Paracoccus pantotrophus according to Rainey et al., 1999) which shed new light on these interesting and unusual conversions of nitrogen compounds (Jetten $e t$ al., 1997). The observation of nitrogen losses during a leachate treatment process (Hippen et al., 1997) prompted us to study the bacterial flora in a leachate treatment plant in Mechernich, Germany. Enrichment by continuous culture was successful and led to the isolation of a bacterial strain, $\mathrm{TL}^{\mathrm{T}}$, which proved to be a heterotrophic nitrifier/aerobic denitrifier (Lukow \& Diekmann, 1997). Although its metabolism revealed similarities to Paracoccus denitrificans DSM 2944, it soon became evident that the strain had peculiar properties.

\footnotetext{
†Present address: Max-Planck-Institut für Terrestrische Mikrobiologie, Marburg, Germany.

The EMBL accession numbers for the $16 \mathrm{~S}$ rDNA sequences of strain TL1 ${ }^{\top}$ and
} $T$. selenatis strain ATCC $55363^{\top}$ are $\mathrm{Y} 17590$ and $\mathrm{Y} 17591$, respectively.
Partial sequencing of the $16 \mathrm{~S}$ rDNA indicated a high relationship between strain $T L 1^{\mathrm{T}}$ and members of the genus Thauera. The few known strains of this genus group with the two species Thauera aromatica and Thauera selenatis, and are well-known for their ability to denitrify (Anders et al., 1995) but have not been reported to denitrify in the presence of oxygen. Results of experiments in conventional taxonomy, as well as chemo- and molecular taxonomy, are reported here which allow the classification of strain $\mathrm{TL}^{\mathrm{T}}$ as a novel species.

\section{METHODS}

Cultivation of bacterial strains. Unless otherwise stated, strain $\mathrm{TL1}^{\mathrm{T}}$ was grown aerobically at $37^{\circ} \mathrm{C}$ in $500 \mathrm{ml}$ Erlenmeyer flasks in $100 \mathrm{ml}$ medium containing $\left(1^{-1}\right): 0 \cdot 30 \mathrm{~g}$ ammonium chloride, $2.93 \mathrm{~g}$ sodium acetate and mineral salts at pH 8 (Robertson \& Kuenen, 1984; Lukow \& Diekmann, 1997). For the preparation of plates, the medium was solidified by addition of $15 \mathrm{~g}_{\text {agar }} \mathrm{l}^{-1}$. Cells for the detection of $\mathrm{N}_{2} \mathrm{O}$ formation and nitrate reductase assays were grown in $100 \mathrm{ml}$ mineral medium (Hooijmans et al., 1990) with the addition of $4.0 \mathrm{~g}$ potassium nitrate $\mathrm{l}^{-1}$. Cells that were used for the detection of poly- $\beta$-hydroxybutyrate were grown in the same medium without nitrate. Cultivation of strain $T L 1^{\mathrm{T}}$ under anaerobic conditions was performed in serum bottles tightly closed with butyl rubber stoppers with a crimped metal seal and the medium was gassed with $\mathrm{O}_{2}$-free nitrogen 
gas as described by Miller \& Wolin (1974). T. aromatica was grown aerobically on a shaker at $30^{\circ} \mathrm{C}$ in $T$. aromatica medium 586 (DSMZ, 1996).

Strain $\mathrm{mXyN} 1$ was grown at $30^{\circ} \mathrm{C}$ in tightly closed 11 glass bottles containing $800 \mathrm{ml}$ medium. The cultures were gently shaken twice a day. The basal medium had the following composition (g deionized water $\left.1^{-1}\right)$ : $\mathrm{NaCl}, 1.00$; $\mathrm{CaCl}_{2} .2 \mathrm{H}_{2} \mathrm{O}, 0 \cdot 10 ; \mathrm{NH}_{4} \mathrm{Cl}, 0 \cdot 25 ; \mathrm{KH}_{2} \mathrm{PO}_{4}, 0.50 ; \mathrm{KCl}, 0.50$; $\mathrm{MgSO}_{4} .7 \mathrm{H}_{2} \mathrm{O}, 0.50$; sodium benzoate, $0.29 ; \mathrm{KNO}_{3}, 0.51(\mathrm{~F}$. Widdel, personal communication). After autoclaving and cooling, $20 \mathrm{ml} \mathrm{NaHCO}$ solution, vitamins, EDTA-chelated mixture of trace elements and selenite and tungstate solution (Widdel \& Bak, 1992) were added. The $\mathrm{pH}$ of the medium was adjusted to $7 \cdot 3$.

$T$. selenatis was grown aerobically on a shaker at $30{ }^{\circ} \mathrm{C}$ in minimal medium containing $0.4 \%$ yeast extract, $20 \mathrm{mM}$ nitrate and $20 \mathrm{mM}$ acetate (Macy et al., 1993).

Phenotypic characterization. For characterization, bacterial strains were cultivated at $27^{\circ} \mathrm{C}$ on agar plates or in LB medium on a shaker at 140 r.p.m. The Gram-reaction was carried out with the test kit Gram colour 2 (Deutsche bioMérieux), and the $\mathrm{KOH}$ test for determining the type of cell wall was done according to Gregsen (1978). The presence of catalase and oxidase was examined as detailed by Smibert \& Krieg (1994). API 20NE was used as described by the manufacturer (Deutsche bioMérieux). Tests for growth on different substrates were performed aerobically and anaerobically at $37^{\circ} \mathrm{C}$ in the medium of Hooijmans et al. (1990) with $4.0 \mathrm{~g}$ potassium nitrate $1^{-1}$; acetate was replaced by $5 \mathrm{mM}$ of the respective substrate.

For the determination of the optimum temperature for growth, strain $\mathrm{TL1}^{\mathrm{T}}$ was grown in $100 \mathrm{ml}$ Erlenmeyer flasks containing $12 \mathrm{ml}$ mineral salt medium with ammonium chloride and acetate (Robertson \& Kuenen, 1984). The flasks were not shaken and were incubated in waterbaths at $34,37,40$ and $44^{\circ} \mathrm{C}$, respectively, with three parallel flasks per temperature. Growth was determined by measurement of $\mathrm{OD}_{578}$ after $0,4,6$ and $8 \mathrm{~h}$.

For the detection of poly- $\beta$-hydroxybutyrate, strain $\mathrm{TL1}^{\mathrm{T}}$ was grown aerobically at $37^{\circ} \mathrm{C}$. When the cultures had reached the stationary phase, heat-fixed smears were prepared. Staining with Nile Blue A was performed according to the method of Ostle \& Holt (1982). The preparations were examined with the fluorescence microscope Axiophot (Zeiss) using an excitation filter of 395-440 nm.

GC detection of $\mathrm{N}_{2} \mathrm{O}$. Cells of $\mathrm{TL}^{\mathrm{T}}$ were grown aerobically at $37^{\circ} \mathrm{C}$ in $500 \mathrm{ml}$ Erlenmeyer flasks and collected by centrifugation. Resuspended cells $\left(5 \mathrm{ml} ; \mathrm{OD}_{578}\right.$ equivalent to 10$)$ were used to inoculate $50 \mathrm{ml} \mathrm{O}$-free mineral medium (Hooijmans et al., 1990) with $1.2 \mathrm{~g}$ potassium nitrate $1^{-1}$ in a $60 \mathrm{ml}$ serum bottle. Incubation was at $37^{\circ} \mathrm{C}$. Samples $(50 \mu \mathrm{l})$ were drawn from the gas space and applied to a Poraplot Qcolumn $(10 \mathrm{~m} \times 0.32 \mathrm{~mm}$ i.d.) in a Chrompack GC model CP 9002. The carrier gas $\left(35 \mathrm{ml} \mathrm{min} \mathrm{mas}^{-1}\right)$ witrogen and the $\mathrm{N}_{2} \mathrm{O}$ signal was detected by an electron capture detector.

Assay of nitrate reductase activity. Cells were grown anaerobically in $125 \mathrm{ml}$ serum bottles and aerobically in $500 \mathrm{ml}$ Erlenmeyer flasks at $37^{\circ} \mathrm{C}$, collected by centrifugation and washed with nitrate-free medium. Protein was estimated by the Lowry method. Nitrate reductase activity was assayed spectrophotometrically at $600 \mathrm{~nm}$ in silicon-stoppered cuvettes using benzyl and methyl viologen as described by Jones \& Garland (1977).
Chemotaxonomy. A modified Marmur procedure (Takahashi, 1993) was used to isolate genomic DNA. The $\mathrm{G}+\mathrm{C}$ content (mol\%) was measured by HPLC after hydrolysis as described by Tamaoka \& Komagata (1984). Lambda DNA was used as a reference.

For whole-cell fatty acid analysis, the bacteria were grown on TSB agar for $48 \mathrm{~h}$ at $28^{\circ} \mathrm{C}$ and two to four loopfuls of bacterial cells were scraped from the Petri dish. Fatty acid methyl esters were obtained by saponification, methylation and extraction of the cells as described previously (Kämpfer $\&$ Kroppenstedt, 1996). The fatty acid methyl ester mixtures were separated using the model $5898 \mathrm{~A}$ microbial identification system (Sasser, 1990).

For analysis of polyamines, freeze-dried cultures obtained from bacterial strains grown on LB medium until the late exponential phase were used. Polyamines were dansylated and extracted with toluene (Scherer \& Kneifel, 1983). Separation was performed according to Busse \& Auling (1988). Dansylated polyamines were determined by a fluorescence detector (model 420-E/420-AC; Waters) with excitation at $360 \mathrm{~nm}$ and a cut-off filter of $450 \mathrm{~nm}$. Quinones were determined by TLC and HPTLC according to Kroppenstedt (1982).

$16 S$ rDNA sequence determination. Genomic DNA extraction, PCR-mediated amplification of the 16S rDNA and purification of PCR products were carried out using procedures described previously (Rainey et al., 1996). Purified PCR products were sequenced using the Taq DyeDeoxy Terminator Cycle Sequencing kit (Applied Biosystems) as directed in the manufacturer's protocol. The Applied Biosystems 310 DNA Genetic Analyzer was used for electrophoresis of the sequence reaction products.

Phylogenetic analysis. The ae 2 editor (Maidak et al., 1994) was used to align the $16 \mathrm{~S}$ rDNA sequence of strains $\mathrm{TL1}^{\mathrm{T}}$ and $T$. selenatis strain ATCC 55363 ${ }^{\mathrm{T}}$ against the $16 \mathrm{~S}$ rDNA sequences of members of the $\beta$-subclass of the Proteobacteria available from the public databases. Pairwise evolutionary distances were computed using the correction of Jukes \& Cantor (1969). The least-squares distance method of De Soete (1983) was used in the construction of the phylogenetic dendrogram from distance matrices.

Nucleotide sequence accession numbers. The strain designations and accession numbers of the reference strains used in the phylogenetic analyses are as follows: $T$. aromatica strain $\mathrm{K} 172^{\mathrm{T}}$, X77118; T. aromatica strain $\mathrm{mXyN1,}$ X83533; $T$. selenatis strain ATCC $55363^{\mathrm{T}}$, X68491; Azoarcus evansii strain KB 740 ${ }^{\mathrm{T}}$, X77679; Azoarcus indigens strain $\mathrm{BH} 72^{\mathrm{T}}$, L15530; Azoarcus tolulyticus strain Tol-4 ${ }^{\mathrm{T}}$, L33694; Zoogloea ramigera strain ATCC $19544^{\mathrm{T}}$, X74913.

DNA-DNA hybridization. Bacterial cells were harvested by centrifugation at $16000 \mathrm{~g}$ for $10 \mathrm{~min}$, washed twice in $0 \cdot 15 \mathrm{M}$ saline/0.10 M EDTA pH 8.0 and, if necessary, stored at $-20^{\circ} \mathrm{C}$. DNA was prepared and DNA-DNA hybridization was done by the thermal renaturation rate method of De Ley et al. (1970) using a Gilford model 2600 spectrophotometer as described previously (Wiese et al., 1996).

\section{RESULTS AND DISCUSSION}

\section{Phenotypic and physiological characterization}

Strain $\mathrm{TL}^{\mathrm{T}}$ was enriched from the rotating biological contactor for nitrification in a leachate treatment plant at Mechernich, Germany, by continuous culture at 
Table 1. Characteristics of different species of the genus Thauera

+ , Positive; (+), weakly positive; -, negative; ND, not determined.

\begin{tabular}{|c|c|c|c|}
\hline Character & $\operatorname{TL1}^{\mathrm{T} *}$ & $\begin{array}{c}\text { T. } \\
172^{\mathrm{T}} \dagger\end{array}$ & T. selenatis $\ddagger$ \\
\hline Cell morphology & Short rods & Short rods & Rods \\
\hline Cell size $(\mu \mathrm{m})$ & $0.75 \times 1.5-2.0$ & $0.5-1.5 \times 1.0-2.5$ & $0.56 \times 1.4$ \\
\hline Motility & + & $(+)$ & + \\
\hline Flagella & Single, polar & $\begin{array}{l}\text { 'Degenerately } \\
\text { peritrichous' }\end{array}$ & Single, polar \\
\hline Catalase reaction & $(+)$ & + & + \\
\hline Oxidase reaction & + & + & + \\
\hline Anaerobic denitrification & $+\left(\right.$ mainly $\left.\mathrm{N}_{2} \mathrm{O}\right)$ & $+\left(\right.$ mainly $\left.\mathrm{N}_{2} \mathrm{O}\right)$ & $+\left(\right.$ to $\left.\mathrm{N}_{2} \mathrm{O}\right)$ \\
\hline Aerobic denitrification & + & ND & ND \\
\hline Selenate respiration & ND & - & + \\
\hline Oxidative metabolism & + & + & + \\
\hline $\mathrm{G}+\mathrm{C}$ content $(\mathrm{mol} \%)$ & 65 & 67 & 66 \\
\hline Optimum growth pH & ND & $7 \cdot 0-7 \cdot 4$ & $\begin{array}{l}8.0 \text { (with nitrate), } \\
7 \cdot 0 \text { (with selenate) }\end{array}$ \\
\hline Optimum growth temp. $\left({ }^{\circ} \mathrm{C}\right)$ & 40 & 28 & $25-30$ \\
\hline Growth factors required & - & - & + \\
\hline Quinone(s) & Ubiquinone Q-8 & ND & Ubiquinone Q-8 \\
\hline \multicolumn{4}{|l|}{ Fatty acids in lipids $(\%): \S$} \\
\hline $10: 03-\mathrm{OH}$ & $4 \cdot 0$ & 4.9 & ND \\
\hline $12: 0$ & $5 \cdot 3$ & 4.9 & ND \\
\hline $16: 1 \omega 7 c i s$ & $46 \cdot 9$ & $40 \cdot 8$ & ND \\
\hline $16: 0$ & $18 \cdot 5$ & $32 \cdot 2$ & ND \\
\hline $18: 1 \omega 7 c i s$ & $16 \cdot 6$ & $13 \cdot 6$ & ND \\
\hline \multicolumn{4}{|l|}{ Hydrolysis of: } \\
\hline Gelatin & + & ND & - \\
\hline Starch & ND & ND & - \\
\hline Urea & - & ND & ND \\
\hline Poly- $\beta$-hydroxybutyrate & ND & + & + \\
\hline
\end{tabular}

* Data from Lukow \& Diekmann (1997).

$\dagger$ Data from Anders et al. (1995), Tschech \& Fuchs (1987) and Song et al. (1998).

$¥$ Data from Rech \& Macy (1992) and Macy et al. (1993).

§Abbreviations: 10:0 3-OH, 3-hydroxy decanoic acid; 16:1 $\omega 7$ cis, cis-9-hexadecenoic acid;

18: $1 \omega 7$ cis, cis-9-octadecenoic acid.

$\mathrm{pO}_{2}$ of $50 \%$ and dilution rate of $0.04 \mathrm{~h}^{-1}$ in an acetate/ammonium chloride-containing medium with a $\mathrm{C} / \mathrm{N}$ ratio of $10 \cdot 5$. Upon a nitrate pulse, a high denitrification rate was observed (Lukow \& Diekmann, 1997). The Gram-negative strain was isolated as a pure culture by repeated streaking on agar plates with a mineral medium (Robertson \& Kuenen, 1984). The cells of strain $T L 1^{\mathrm{T}}$ are slightly curved rods of $1.5-2.0 \mu \mathrm{m}$ length and $0.75 \mu \mathrm{m}$ width. Acetate can be replaced by propionate, butyrate or ethanol, but not by methanol (Lukow \& Diekmann, 1997). A single polar flagellum $(2 \mu \mathrm{m}$ long; determined by scanning electron microscopy) is observed, which is similar to that of T. selenatis (Macy et al., 1993), but different from the 'degenerately peritrichous' type found in $T$. aromatica $\mathrm{K} 172^{\mathrm{T}}$ (Song et al., 1998). When grown in the absence of nitrate, cells accumulated large amounts of storage materials. Cells exhibited a bright orange fluorescence in the test for the presence of poly- $\beta$ hydroxybutyrate indicating a positive result. We tried to identify the strain by performing the API $20 \mathrm{NE}$ test. The code obtained, 1004667, did not point to any of the bacterial species listed in the Analytical Profile Index. Some characters pointed to the genus Zoogloea, but only the chemotaxonomic data and the partial sequencing of the 16S rDNA gave evidence for its relation to the genus Thauera. The characters of strain $\mathrm{TL} 1^{\mathrm{T}}$ were compared to other strains in this genus and are described in Table 1. The optimum growth temperature was $40^{\circ} \mathrm{C}$. Growth rates between 6 and $8 \mathrm{~h}$ of cultivation at $40^{\circ} \mathrm{C}$ were twice as high as those at $37^{\circ} \mathrm{C}$, and the growth rate fell sharply as the temperature increased beyond this point, eventually reaching zero. 


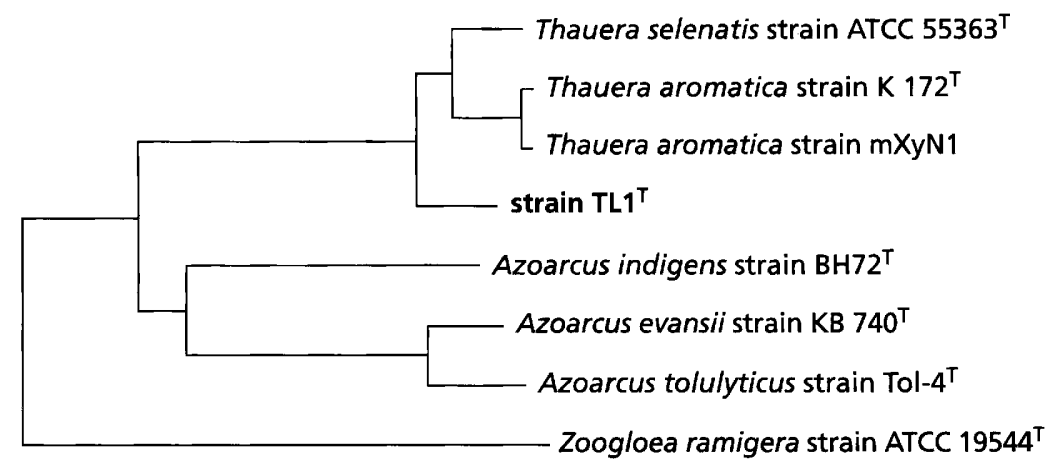

$2 \cdot 5 \%$
Fig. 1. Phylogenetic position of strain $\mathrm{TL}^{\top}{ }^{\top}$ among members of the $\beta$-subclass of the Proteobacteria.
Under aerobic conditions, strain $\mathrm{TL} 1^{\mathrm{T}}$ used acetate, 2aminobenzoate, benzoate, L-glutamate, 4-hydroxybenzoate, L-leucine, phenyl acetate and DL-phenylalanine (weak growth), but not phenol. All these substances, including phenol, were used anaerobically as a substrate.

Special attention was given to the denitrification abilities under aerobic conditions and the formation of $\mathrm{N}_{2} \mathrm{O}$ under anaerobiosis. Tests were carried out as described by G. Fuchs (personal communication; volume ratio gas phase/liquid phase was $1 / 11, \mathrm{KNO}_{3}$ concentration was $1.20 \mathrm{~g} \mathrm{l}^{-1}$ ). Three hours after inoculation, $\mathrm{N}_{2} \mathrm{O}$ was identified in the gas space. It was observed that $\mathrm{N}_{2} \mathrm{O}$ peaks diminished with time and were not detectable after $18 \mathrm{~h}$.

Micro-organisms showing aerobic nitrate respiration have been characterized by the investigation of levels of membrane-bound and periplasmic nitrate reductases (Bell et al., 1990; Carter et al., 1995a). Tests following the protocol of Jones \& Garland (1977) revealed that in strain $T L 1^{\mathrm{T}}$, the ratios of nitrate reduction using benzyl and methyl viologen as electron donors do not differ significantly when the cells were grown either aerobically or anaerobically. This indicates that the nitrate reductase is of the periplasmic type and no additional cytoplasmic nitrate reductase is induced under anaerobic growth conditions as has recently been shown for the newly isolated Pseudomonas putida 2.9 (Carter et al., 1995b). The ability of strain $\mathrm{TL1}^{\mathrm{T}}$ to carry out heterotrophic nitrification was calculated from balances in continuous culture (Lukow \& Diekmann, 1997).

\section{Chemotaxonomic characterization}

Major cellular non-polar fatty acids detected in strain $\mathrm{TL}^{\mathrm{T}}$ are $16: 1,16: 0$ and $18: 1 \omega 7 \mathrm{cis}$, and hydroxylated fatty acids are 10:03-OH and 12:03-OH. Similar data were found for T. aromatica $6964^{\mathrm{T}}$ and $A$. evansii DSM $6898^{\mathrm{T}}$. Existing quantitative differences do not seem to be valid for differentiation within the group. Ubiquinone Q-8 was detected, but not rhodoquinone. Polyamine analysis revealed $60.5 \mu \mathrm{mol}$ hydroxy- putrescine (g dry $\mathrm{wt})^{-1}, 11 \cdot 1 \mu \mathrm{mol}$ spermidine (g dry $\mathrm{wt})^{-1}, 4 \cdot 7 \mu \mathrm{mol}$ cadaverine (g dry $\left.\mathrm{wt}\right)^{-1}$ and $4.4 \mu \mathrm{mol}$ putrescine (g dry wt) $)^{-1}$

\section{Phylogenetic analyses}

The almost complete 16S rDNA sequences of strains $\mathrm{TL1}^{\mathrm{T}}$ and Thauera selenatis strain ATCC $55363^{\mathrm{T}}$, comprising 1491 nucleotides $(>95 \%$ of the Escherichia coli sequence; Brosius et al., 1978), were determined in this study. The phylogenetic dendrogram shown in Fig. 1 was reconstructed from evolutionary distances (Jukes \& Cantor, 1969) by the leastsquares distance method (De Soete, 1983). A total of 1428 nucleotides present in all strains between positions 38 and 1482 (E. coli positions) were used for these analyses. The sequence of $T$. selenatis strain ATCC $55363^{\mathrm{T}}$ was re-determined in this study since the original sequence (X68491) was not complete and comprised only 1336 nucleotide positions between 33 and 1376 ( $E$. coli positions). The original sequence of T. selenatis strain ATCC $55363^{\mathrm{T}}$ (X68491) had $99 \cdot 0 \%$ similarity when compared to the sequence of $T$. selenatis strain ATCC $55363^{\mathrm{T}}$ determined in this study (Y17591), the original sequence was not used in the analyses presented in this study.

The 16S rDNA sequence-based phylogenetic tree shown in Fig. 1 indicates the position of strain TL $1^{\mathrm{T}}$ within the radiation of the species of the genera Thauera and Azoarcus. Z ramigera was used as an outgroup in these analyses. 16S rDNA similarity values between the sequences included in the analyses (Fig. 1) and that of strain $\mathrm{TL} 1^{\mathrm{T}}$ indicate that strain $\mathrm{TL1}^{\mathrm{T}}$ is most closely related at the $16 \mathrm{~S}$ rDNA level to members of the genus Thauera. The similarity values of the sequence of strain $\mathrm{TL}^{\mathrm{T}}$ to the species of the genus Thauera are as follows: $98.5 \%$ similarity to $T$. aromatica strain $\mathrm{K} 172^{\mathrm{T}} ; 98.7 \%$ similarity to $T$. aromatica strain $\mathrm{mXyN} 1$; and $98.5 \%$ similarity to $T$. selenatis strain ATCC $55363^{\mathrm{T}}$. The $16 \mathrm{~S}$ rDNA sequence similarity values between strain $\mathrm{TL1}^{\mathrm{T}}$ and species of the genus Azoarcus were in the range $94 \cdot 7-95 \cdot 0 \%$. 
Table 2. DNA-DNA hybridization studies

Mean values are given; numbers of determinations are shown in parentheses.

\begin{tabular}{|c|c|c|c|c|}
\hline \multirow[t]{2}{*}{ Strain } & \multicolumn{4}{|c|}{ Reassociation (\%) with: } \\
\hline & DSM 12266 & DSM 6984 ${ }^{\mathrm{T}}$ & Strain mXyN1 & $\operatorname{ATCC} 55363^{\mathrm{T}}$ \\
\hline T. mechernichensis DSM $12266^{\mathrm{T}}$ & 100 & & & \\
\hline T. aromatica DSM $6984^{\mathrm{T}}$ & $27(4)$ & 100 & & \\
\hline Strain $\mathrm{mXyN} 1$ & $39(2)$ & $90(3)$ & 100 & \\
\hline T. selenatis ATCC $55363^{\mathrm{T}}$ & $25(2)$ & $43(2)$ & $27(2)$ & 100 \\
\hline
\end{tabular}

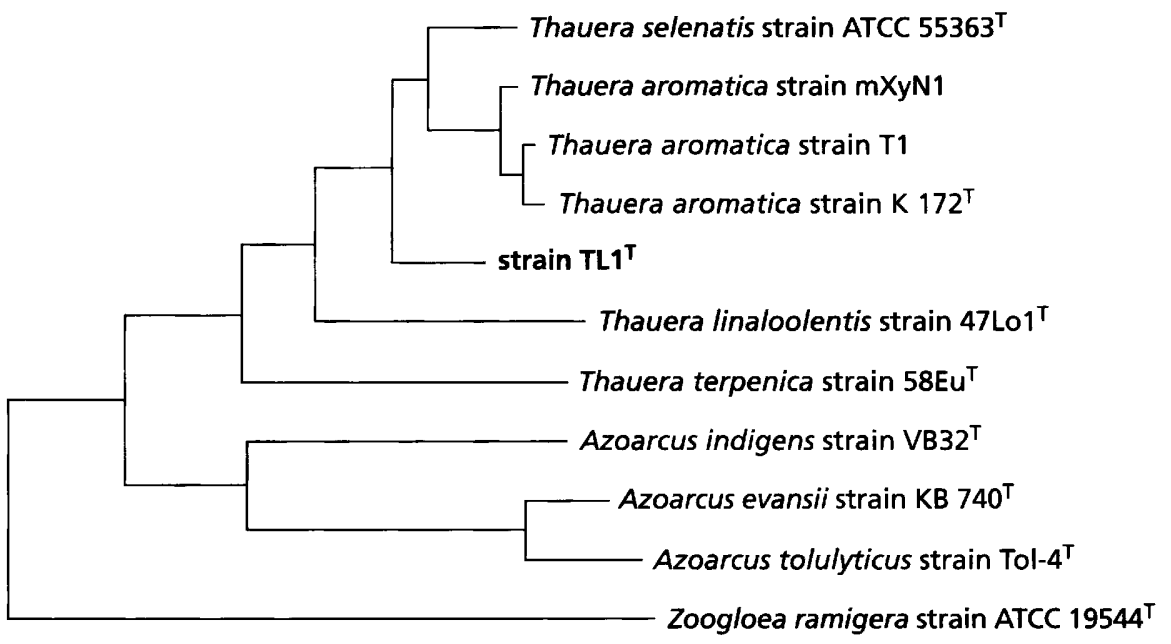

Fig. 2. Phylogenetic position of all known members of the genus Thauera.

DNA-DNA hybridization experiments within the genus Thauera compared strain $\mathrm{TL1}^{\mathbf{T}}$ to $T$. selenatis (Macy et al., 1993), T. aromatica (Anders et al., 1995) and strain mXyN1 (Rabus \& Widdel, 1995). The data presented in Table 2 show that the toluene-degrading, denitrifying strain $\mathrm{mXyN} 1$ hybridized well with $T$. aromatica DSM $6984^{\mathrm{T}}$ and is therefore identified as belonging to that species according to Wayne et al. (1987). On the other hand, a low degree of similarity $(25-39 \%)$ between strain $\mathrm{TL}^{\mathrm{T}}$ and the three other members of the genus Thauera was observed. Since it is generally accepted that among strains of the same species the levels of DNA similarity should be equal to or greater than $70 \%$, strain $T L 1^{\mathrm{T}}$ cannot be allocated to any of the three known species of the genus Thauera and constitutes a new species in the genus Thauera on the basis of DNA relatedness.

\section{Comparison with species belonging to the genus Thavera}

While the presently recognized species of the genus Thauera are characterized either by their abilities to reduce selenate or to degrade aromatic compounds anaerobically, the new species proposed here was enriched and characterized by its ability for heterotrophic nitrification and aerobic denitrification (Lukow \& Diekmann, 1997). Further investigation of physiological, chemotaxonomic and phylogenetic characters revealed (as shown in Table 1) that there are few differences, but the distinctness of the 16S rDNA sequence of strain $\mathrm{TLl}^{\mathrm{T}}$ from those of the two previously described species of the genus Thauera are in congruence with the results of the DNA-DNA experiments indicating its novel species status. A distinction from other species of the genus is possible due to its optimal temperature for growth $\left(40^{\circ} \mathrm{C}\right)$, which may reflect an adaptation to the special conditions of the natural habitat of strain $\mathrm{TL}^{\mathrm{T}}$. The finding that strain $\mathrm{TL1}^{\mathrm{T}}$ has an active periplasmic nitrate reductase deserves further investigation.

\section{Description of Thauera mechernichensis sp. nov.}

Thauera mechernichensis (me.cher.ni.chen'sis. M.L. adj. mechernichensis pertaining to Mechernich, because the organism was isolated from the leachate treatment plant at Mechernich, Germany).

Gram-negative, slightly curved, rod-shaped cells are $1.5-2.0 \mu \mathrm{m}$ long and $0.75 \mu \mathrm{m}$ wide, have rounded ends 
and contain granules of poly- $\beta$-hydroxybutyrate in the stationary growth phase. Cells are highly motile, having one polar flagellum $2 \mu \mathrm{m}$ long. The optimum temperature of growth is $40^{\circ} \mathrm{C}$. Cells are oxidasepositive and weakly catalase-positive. Translucent, white-yellow, slimy colonies on mineral salts medium containing acetate and ammonium chloride are $1 \mathrm{~mm}$ in diameter after growth at $37^{\circ} \mathrm{C}$ for $48 \mathrm{~h}$. Preferred growth substrates are acetate, propionate, butyrate and ethanol. It cannot use methanol. Many aromatic compounds as well as malate and citrate are used as sole carbon sources under denitrifying conditions. $\mathrm{N}_{2} \mathrm{O}$ is formed anaerobically but can then be used as electron acceptor. Phylogenetically, T. mechernichensis is a member of the $\beta$-subclass of the Proteobacteria, ubiquinone Q-8 being the major quinone and 2hydroxyputrescine the specific polyamine. This organism was isolated from the nitrification step in a leachate treatment plant. The type strain is $\operatorname{TL}^{\mathrm{T}}(=$ DSM $\left.12266^{\mathrm{T}}\right)$. The DNA $\mathrm{G}+\mathrm{C}$ composition is $64.9 \mathrm{~mol} \%$.

\section{NOTE ADDED IN PROOF}

After submission of the manuscript, a publication by S. Foss \& J. Harder [Syst Appl Microbiol 21, 365-373 (1998)] appeared describing two new species of the genus Thauera. The $16 \mathrm{~S}$ rDNA sequence similarity values of the sequence of strain $\mathrm{TL}^{\mathrm{T}}$ to the new Thauera species are as follows: $96.9 \%$ similarity to Thauera linaloolentis strain $47 \mathrm{Lol}^{\mathrm{T}}$; and $96.7 \%$ similarity to Thauera terpenica strain $58 \mathrm{Eu}^{\mathrm{T}}$. To evaluate the position of all known Thauera species, a new phylogenetic dendrogram was constructed (Fig. 2) using the nucleotide sequence accession numbers as follows: $T$. linaloolentis strain $47 \mathrm{Lol}^{\mathrm{T}}$, AJ005816; T. terpenica strain $58 \mathrm{Eu}^{\mathrm{T}}$, AJ005817, as well as T. aromatica strain T1, U95176 (Song et al., 1998).

\section{ACKNOWLEDGEMENTS}

This work was supported by a grant from the BMBF, Projektträger Karlsruhe. We would like to thank Professor G. Fuchs, Freiburg, for valuable hints concerning the determination of $\mathrm{N}_{2} \mathrm{O}$, Professor F. Widdel, Bremen, for the strain $\mathrm{mXyN1}$ and its growth medium, and Professor J. M. Macy, Department of Microbiology, LaTrobe University, Melbourne, Australia, for making the type strain of $T$. selenatis available for the taxonomic studies in this paper.

\section{REFERENCES}

Anders, H. J., Kaetzke, A., Kämpfer, P., Ludwig, W. \& Fuchs, G. (1995). Taxonomic position of aromatic-degrading denitrifying Pseudomonad strains K 172 and KB 740 and their description as new members of the genera Thauera, as Thauera aromatica sp. nov., and Azoarcus, as Azoarcus evansii sp. nov., respectively, members of the beta subclass of the Proteobacteria. Int $J$ Syst Bacteriol 45, 327-333.

Bell, L. C., Richardson, D. J. \& Ferguson, S. J. (1990). Periplasmic and membrane-bound respiratory nitrate reductases in
Thiosphaera pantotropha: the periplasmic enzyme catalyses the first step in aerobic denitrification. FEBS Lett 265, 85-87.

Brosius, J., Palmer, M. L., Kennedy, P. J. \& Noller, H. F. (1978). Complete nucleotide sequence of the 16S ribosomal RNA gene from Escherichia coli. Proc Natl Acad Sci USA 75, 4801-4805.

Busse, J. \& Auling, G. (1988). Polyamine pattern as chemotaxonomic marker within the Proteobacteria. Syst Appl Microbiol 11, 1-8.

Carter, J. P., Hsiao, Y. H., Spiro, S. \& Richardson, D. J. (1995a). Soil and sediment bacteria capable of aerobic nitrate respiration. Appl Environ Microbiol 61, 2852-2858.

Carter, J. P., Richardson, D. J. \& Spiro, S. (1995b). Isolation and characterization of a strain of Pseudomonas putida that can express a periplasmic nitrate reductase. Arch Microbiol 163, 159-166.

De Ley, J., Cattoir, H. \& Reynaerts, A. (1970). The quantitative measurement of DNA hybridization from renaturation rates. Eur J Biochem 12, 133-142.

De Soete, G. (1983). A least squares algorithm for fitting additive trees to proximity data. Psychometrika 48,621-626.

DSMZ (1996). Catalogue of Strains. Supplement 1996. German Collection of Microorganisms and Cell Cultures. Braunschweig: DSMZ.

Gregsen, T. (1978). Rapid method for distinction of gramnegative from gram-positive bacteria. Eur J Appl Microbiol 5, 123-127.

Hippen, A., Rosenwinkel, K.-H., Baumgarten, G. \& Seyfried, C. F. (1997). Aerobic deammonification: a new experience in the treatment of wastewaters. Water Sci Technol 35, 111-120.

Hooijmans, C. M., Geraats, S. G. M., van Niel, E. W. J., Robertson, L. A., Heijnen, J. J. \& Luyben, K. C. A. M. (1990). Determination of growth and coupled nitrification/denitrification by immobilized Thiosphaera pantotropha using measurement and modeling of oxygen profiles. Biotechnol Bioeng 36, 931-939.

Jetten, M. S. M., Logemann, S., Muyzer, G., Robertson, L. A., de Vries, S., van Loosdrecht, M. C. M. \& Kuenen, J. G. (1997). Novel principles in the microbial conversion of nitrogen compounds. Antonie Leeuwenhoek J Microbiol Serol 71, 75-93.

Jones, R. W. \& Garland, P. B. (1977). Sites and specificity of the reaction of bipyridylium compounds with the anaerobic respiratory enzymes of Escherichia coli. Biochem $J$ 164, 199-211.

Jukes, T. H. \& Cantor, C. R. (1969). Evolution of protein molecules. In Mammalian Protein Metabolism, vol. 3, pp. 21-132. Edited by H. N. Munro. New York: Academic Press.

Kämpfer, P. \& Kroppenstedt, R. M. (1996). Numerical analysis of fatty acid patterns of coryneform bacteria and related taxa. Can $J$ Microbiol 42, 989-1005.

Kroppenstedt, R. M. (1982). Anwendung chromatographischer HP-Verfahren (HPTLC und HPLC) in der BakterienTaxonomie. GIT Lab Med 5, 266-275.

Lukow, T. \& Diekmann, H. (1997). Aerobic denitrification by a newly isolated heterotrophic bacterium strain TL1. Biotechnol Lett 19, 1157-1159.

Macy, J. M., Rech, S., Auling, G., Dorsch, M., Stackebrandt, E. \& Sly, L. I. (1993). Thauera selenatis gen. nov., sp. nov., a member of the beta subclass of Proteobacteria with a novel type of anaerobic respiration. Int $J$ Syst Bacteriol 43, 135-142.

Maidak, B. L., Larsen, N., McCaughey, M. J., Overbeek, R., Olsen, G. J., Fogel, K., Blandy, J. \& Woese, C. R. (1994). The Ribosomal Database Project. Nucleic Acids Res 22, 3485-3487.

Miller, T. L. \& Wolin, M. J. (1974). A serum bottle modification of 
the Hungate technique for the cultivation of obligate anaerobes. Appl Microbiol 27, 985-987.

Ostle, A. G. \& Holt, J. G. (1982). Nile Blue A as a fluorescent stain for poly- $\beta$-hydroxybutyrate. Appl Environ Microbiol 44, 238-241.

Rabus, R. \& Widdel, F. (1995). Anaerobic degradation of ethylbenzene and other aromatic hydrocarbons by new denitrifying bacteria. Arch Microbiol 163, 96-103.

Rainey, F. A., Ward-Rainey, N., Kroppenstedt, R. M. \& Stackebrandt, E. (1996). The genus Nocardiopsis represents a phylogenetically coherent taxon and a distinct actinomycete lineage: proposal of Nocardiopsaceae fam. nov. Int $J$ Syst Bacteriol 46, 1088-1092.

Rainey, F. A., Kelly, D. P., Stackebrandt, E., Burkhardt, J., Hiraishi, A., Katayama, Y. \& Wood, A. (1999). A re-evaluation of the taxonomy of Paracoccus denitrificans and a proposal for the creation of Paracoccus pantotrophus comb. nov. Int J Syst Bacteriol (in press).

Rech, S. A. \& Macy, J. M. (1992). The terminal reductases for selenate and nitrate respiration in Thauera selenatis are two distinct enzymes. J Bacteriol 174, 7316-7320.

Robertson, L. A. \& Kuenen, J. G. (1984). Aerobic denitrification: a controversy revived. Arch Microbiol 139, 351-354.

Sasser, M. (1990). Identification of bacteria by gas chromatography of cellular fatty acids. Technical Note 101. Newark, DE: MIDI.

Scherer, P. \& Kneifel, H. (1983). Distribution of polyamines in methanogenic bacteria. J Bacteriol 154, 1315-1322.

Smibert, R. M. \& Krieg, N. R. (1994). Phenotypic characterization. In Methods for General and Molecular Bacteriology, pp.
607-654. Edited by P. Gerhardt, R. G. E. Murray, W. A. Wood $\&$ N. R. Krieg. Washington, DC: American Society for Microbiology.

Song, B., Young, L. Y. \& Palleroni, N. J. (1998). Identification of denitrifier strain $\mathrm{T} 1$ as Thauera aromatica and proposal for emendation of the genus Thauera definition. Int J Syst Bacteriol 48, 889-894.

Takahashi, M. (1993). An improved method for DNA preparation from lactic acid bacteria resistant to lytic enzymes and its application to bacterial systematics. $\mathrm{PhD}$ thesis, Tokyo University of Agriculture.

Tamaoka, J. \& Komagata, K. (1984). Determination of DNA base composition by reversed-phase high-performance liquid chromatography. FEMS Microbiol Lett 25, 125-128.

Tschech, A. \& Fuchs, G. (1987). Anaerobic degradation of phenol by pure cultures of newly isolated denitrifying pseudomonads. Arch Microbiol 148, 213-217.

Verstraete, W. (1975). Heterotrophic nitrification in soils and aqueous media. Izv Akad Nauk SSSR Ser Biol 4, 541-558.

Wayne, L. G., Brenner, D. J., Colwell, R. R. \& 9 other authors (1987). International Committee on Systematic Bacteriology. Report of the ad hoc committee on reconciliation of approaches to bacterial systematics. Int J Syst Bacteriol 37, 463-464.

Widdel, F. \& Bak, F. (1992). Gram-negative mesophilic sulfatereducing bacteria. In The Prokaryotes, 2nd edn, pp. 3352-3378. Edited by A. Balows, H. G. Trüper, M. Dworkin, W. Harder \& K. H. Schleifer. Heidelberg: Springer.

Wiese, B. G., Strohmar, W., Rainey, F. A. \& Diekmann, H. (1996). Lactobacillus panis sp. nov., from sourdough with a long fermentation period. Int $J$ Syst Bacteriol 46, 449-453. 